\title{
ANALSIS PERAMALAN PENJUALAN TEPUNG TAPIOKA DI CV. XYZ LAMPUNG
}

\author{
Analysis forecasting sales of tapioca flour products in CV. XYZ lampung \\ Masmulki Daniro Jyoti , Rizki Adrianto * \\ *Balai Riset dan Standardisasi Industri Bandar Lampung \\ Jl. Soekarno Hatta KM.1, Rajabasa, Rajabasa Raya, Kec. Rajabasa, Kota Bandar Lampung, Lampung \\ 35142 \\ Email: daniro_mdj@yahoo.com, Rizki1083@gmail.com
}

\begin{abstract}
Abstrak
Penelitian ini dilatarbelakangi oleh tidak menentunya penjualan tepung tapioka yang dialami industri tapioka CV. XYZ. Hal tersebut membuat perusahaan kurang mampu mengoptimalkan modal serta laba perusahaannya. Tujuan penelitian ini adalah untuk menganalisis metode peramalan penjualan yang paling sesuai untuk tepung tapioka CV. XYZ. Sangat penting dilakukan peramalan penjualan dengan menggunakan software POM QM Version 5.2. Analisis peramalan penjualan (forecasting) menggunakan lima metode yaitu Linear Regression, Moving Average, Weighted Moving Average, Exponential Smoothing, dan exponential smoothing with trend dengan menggunakan data penjualan tepung tapioka 5 (lima) tahun terakhir. Hasil analisis menunjukkan bahwa metode Linear Regresi merupakan metode forecasting yang paling sesuai digunakan dalam penjualan industri tapioka CV. XYZ dengan nilai MAD, MSE, dan MAPE terkecil dibandingkan metode lainnya yaitu sebesar $3424,9,14.948 .800$, dan 13,43 \%, dengan hasil peramalan pada tahun 2020 sebesar 21.800 ton tepung tapioka.
\end{abstract}

Kata Kunci: Peramalan, Tapioka, Linear Regresi.

\begin{abstract}
This research was motivated by the uncertainty in the sales of tapioca flour which weakened the tapioca industry of CV. XYZ. This makes the company less able to optimize the company's capital and profits. The purpose of this study was to analyze the most suitable sales forecasting method for tapioca flour CV. XYZ. It is very important to forecast sales using POM QM version 5.2 software. Sales forecasting analysis (forecasting) uses five methods, namely Linear Regression, Moving Average, Weighted Moving Average, Exponential Smoothing, and exponential smoothing with trends using tapioca flour sales data for the last 5 (five) years. The results of the analysis show that the Linear Regression method is a suitable forecasting method used in the industrial sales of tapioca CV. XYZ with MAD, MSE, and MAPE values compared to other methods, namely 3424.9, 14,948,800, and 13.43\%, with forecast results in 2020 of 21,800 tons of tapioca flour.
\end{abstract}

Keywords : Forecasting, Tapioca, Linear Regression.

\section{Pendahuluan}

Ubi kayu merupakan komoditas tanaman pangan ketiga Indonesia setelah padi dan jagung sekaligus sumber kalori pangan termurah dan cukup ketersediaannya. Ubi kayu Indonesia terutama digunakan untuk bahan pangan (58\%), bahan baku industri (28\%), ekspor dalam bentuk

gaplek (8\%) dan pakan (2\%) (Direktorat Pengolahan Hasil Pertanian, 2012).

Tepung tapioka dibuat dari hasil penggilingan ubi kayu yang diekstraksi. Ubi kayu tergolong polisakarida yang mengandung pati dengan kandungan amilopektin yang tinggi tetapi lebih rendah daripada ketan yaitu amilopektin $83 \%$ dan amilosa $17 \%$, sedangkan buah-buahan termasuk 
polisakarida yang mengandung selulosa dan pektin (Winarno, 2004).

Penjualan tepung tapioka di CV. XYZ sempat mengalami penurunan pada tahun 2016 yakni 21.400 ton/tahun dibanding tahun sebelumnya mencapai 328.830 ton/tahun. Pada tahun 2016 tingkat pertumbuhan penjualan ubi kayu di CV. XYZ merosot sampai $39,18 \%$.

CV. XYZ terletak di Desa Bangun Sari, Negeri Katon, Kabupaten Pesawaran, Lampung dimana industri ini memproduksi dan menjual tepung tapioka. Kegiatan penjualan ini ditujukan untuk memberikan kepuasan kepada penjual maupun pembeli. Hal ini dapat dicapai dengan baik bila perusahaan dapat menetapkan usaha-usaha penjualan, sebab penjualan merupakan salah satu usaha pokok yang dilakukan oleh perusahaan, yang mana permasalahan tersebut membuat industri CV. $\mathrm{XYZ}$ harus mengurangi produksi tapioka sehingga laba perusahaan tersebut menurun (Prajawantoro, 2015).

Seorang manejer selalu berkeinginan untuk dapat memperkirakan atau memprediksikan besarnya seluruh permintaan jangka pendek atau jangka panjang sekalipun untuk masing - masing produknya. Dalam kaitannya dengan penyusunan rencana penjualan, informasi yang diperoleh dari peramalan penjualan akan memberikan gambaran berguna tentang prospek permintaan produk tersebut di pasar. Baik atau tidaknya prospek penjualan suatu produk pada dasarnya tidak hanya berdasarkan kemampuan ataupun penggunaan metode peramalan yang tepat. Namun yang tidak kalah pentingnya adalah proses perencanaan produksi yang menentukan terhadap mutu atau kualitas produk, penilaian pasar yang menentukan jenis pasar, kebijakan promosi dan pemasaran yang menentukan cerahnya prospek produk kedepannya. Hal ini secara langsung ataupun tidak, akan berpengaruh terhadap manajemen persediaan perusahaan dan ini menunjukkan keterkaitan di antara faktor-faktor tersebut (Wardah, 2016).

Perencanaan strategi penjualan yang baik sangat diperlukan sehingga dapat mengantisipasi setiap kegiatan perusahaan yang dapat dilihat dari ancaman maupun peluang bagi perusahaan dengan mempertimbangkan faktor kekuatan dan kelemahan perusahaan. Untuk meningkatkan nilai penjualan, perusahaan melakukan berbagai usaha pemasaran melalui bauran pemasaran. Selain itu pula harus diperhatikan faktor-faktor dari luar perusahaan yaitu perusahaan pesaing, peraturan pemerintah, dan teknologi (Prajawantoro, 2015).

\section{Metode Penelitian}

Metode penelitian ini menggunakan studi kasus dan kepustakaan yang bertujuan untuk dapat menganalisa secara teoritis terhadap masalahmasalah yang berhubungan dengan penelitian. Data didapatkan dengan wawancara hasil penjualan dari 5 tahun terakhir dari tahun 2015 sampai 2019. Studi kepustakaan dilakukan dengan membaca berbagai text book, jurnal dan artikel yang relevan serta sumber-sumber lain guna memperoleh data sekunder. Pada penelitian ini dilakukan pengumpulan data yang berkaitan dengan data penjualan dari CV. XYZ. Analisis data menggunakan software POM QM Versi 5.2 dengan metode Forecasting yaitu : Linear Regression, Moving Average, Weighted Moving Average, Exponential Smoothing dan Exponential Smoothing with Trend. Pengukuran Relatif menggunakan indikator Mean Absolute Deviation (MAD), Mean Squared Error (MSE) dan Mean Absolute Percentage Error (MAPE).

\section{Peramalan Penjualan (Forecasting)}

Analisis peramalan penjualan (forecasting) menggunakan beberapa metode yaitu Linear Regression, Moving Average, Weighted Moving Average, Exponential Smoothing, dan exponential smoothing with trend.

\section{Linear Regression}

Regresi adalah sebuah metode matematika untuk menggambarkan hubungan antar variabel. Kata linier menunjukan bahwa hubungannya adalah proporsional secara linier. Model regresi yang paling sederhana melibatkan sebuah variabel tak bebas dan sebuah variabel bebas (Assauri, 2004). Menurut Bahagia (2006), bentuk model Linear Regression adalah :

$$
\mathrm{Y}^{\prime}=\mathrm{a}+\mathrm{bX}
$$


Keterangan:

$Y^{\prime}$

= Nilai yang diramalkan

(penjualan tepung tapioka dalam ton)

a $\quad=$ Konstanta (intercept)

$\mathrm{b}=$ Koefisien regresi (slope)

X $\quad$ Variabel yang

mempengaruhi (waktu:

tahun, bulan, hari)

\section{Moving Average}

Metode peramalan Moving Average merupakan peramalan yang didasarkan pada ratarata aritmatika yang didapatkan dari data pada masa lampau. Teknik peramalan permintaan menggunakan Moving Average diperkiran dengan menghitung rata-rata permintaan aktual dari jumlah tertentu pada periode sebelumnya (Baroto, 2002). Menurut Gitosudarmo (2002), bentuk dari metode Moving Average adalah :

$$
\mathrm{Y}^{\prime}{ }_{t+1}=\frac{\mathrm{T}_{\mathrm{t}-\mathrm{n}+1}+\cdots+\mathrm{T}_{\mathrm{t}+1}+\mathrm{T}_{\mathrm{t}}}{\mathrm{n}}
$$

\section{Keterangan}

$$
\begin{array}{ll}
\mathrm{Y}_{t+1}^{\prime} & =\text { Nilai peramalan periode } \\
\mathrm{t}+1 & = \\
\mathrm{T}_{\mathrm{t}} & \text { Nilai rill periode ke-t } \\
\mathrm{n} & =\text { Jumlah deret waktu yang } \\
& \text { digunakan }
\end{array}
$$

\section{A. Weighted Moving Average}

Metode peramalah Weighted Moving Average merupakan peramalan lebih lanjut dari Moving Average dimana setiap deret waktu lampau diberikan bobot tertentu dan mungkin diberi bobot yang berbeda-beda (Handoko, 2014). Menurut Heizer dan Render (2010), bentuk dari metode Weighted Moving Average adalah:

$$
Y^{\prime}{ }_{t}=\frac{W_{1} A_{t-1}+W_{2} A_{t-2}+\cdots+W_{n} A_{t-n}}{n}
$$

Keterangan:

$$
\begin{array}{ll}
Y^{\prime}{ }_{\mathrm{t}} & =\text { Nilai peramalan periode } \mathrm{t} \\
\mathrm{W}_{1} & =\text { Bobot yang diberikan pada } \\
& \text { periode } \mathrm{t}-1
\end{array}
$$

$$
\begin{aligned}
\mathrm{W}_{2} & =\text { Bobot yang diberikan pada } \\
& \text { periode } \mathrm{t}-2 \\
\mathrm{~W}_{\mathrm{n}} & =\text { Bobot yang diberikan pada } \\
& \text { periode } \mathrm{t}-\mathrm{n} \\
\mathrm{n} & =\text { Jumlah periode }
\end{aligned}
$$

\section{B. Exponential Smoothing}

Metode Exponential Smoothing adalah suatu prosedur yang secara terus menerus memperbaiki peramalan (smoothing) dengan merata-ratakan nilai masa lalu dari suatu data deret waktu dengan cara menurun (exponential) (Indrajit et al., 2003). Menurut Nasution, dkk. (2008), bentuk model Exponential Smoothing adalah:

$$
\mathrm{S}_{\mathrm{t}}=\alpha * \mathrm{Xt}+(1-\alpha) * S_{t-1}
$$

\section{Keterangan:}

$S_{t} \quad=$ Peramalan untuk periode $\mathrm{t}$

$\mathrm{S}_{\mathrm{t}-1}=$ Peramalan pada waktu $\mathrm{t}-1$

$\alpha=$ Konstanta perataan antara 0 dan 1

$\mathrm{Xt}+(1-\alpha)=$ Nilai aktual time series

C. Exponential Smoothing with Trend

Model Exponential Smoothing with Trend merupakan salah satu analisis Exponential Smoothing yang menganalisa deret waktu, dan merupakan metode peramalan dengan memberi nilai pembobot pada serangkaian pengamatan sebelumnya untuk memprediksi masa depan (Rangkuti, 2004). Menurut Ristono (2009), bentuk model Exponential Smoothing with Trend adalah :

$$
\mathrm{T}_{\mathrm{t}}=\beta\left(\mathrm{S}_{\mathrm{t}}-\mathrm{S}_{\mathrm{t}-1}\right)+(1-\beta) \mathrm{T}_{\mathrm{t}-1}
$$

Keterangan:

$\mathrm{T}_{\mathrm{t}} \quad=$ Peramalan untuk periode $\mathrm{t}$

$\mathrm{T}_{\mathrm{t}-1}=$ Peramalan pada waktu $\mathrm{t}-1$

$\beta=$ Konstanta dengan nilai antara 0 dan 1

$\mathrm{S}_{\mathrm{t}} \quad=$ Permintaan nyata periode $\mathrm{t}$

$\mathrm{S}_{\mathrm{t}-1}=$ Permintaan nyata periode $\mathrm{t}-1$ 


\section{Pengukuran Relatif}

Pengukuran relatif digunakan untuk mengetahui besar kesalahan sebuah peramalan. Besar kesalahan sebuah peramalan (nilai eror) dapat diketahui dengan menghitung selisih antara nilai asli dengan nilai ramalan (Subagya, 1994). Menurut Yamit (2003), berikut ini merupakan beberapa cara pengukuran yang digunakan untukmengetahui besarnya kesalahan yang dihasilkan oleh model peramalan:

\section{A. Mean Absolute Deviation (MAD)}

Mean Absolute Deviation (MAD) merupakan ukuran utama dari kesalahan perkiraan dari seluruh model peramalan. Nilai eror dihitung dengan membagi jumlah nilai absolut dari kesalahan perkiraan dengan jumlah periode. Mean Absolute Deviation (MAD) paling berguna ketika orang yang menganalisa ingin mengukur kesalahan ramalan dalam unit yang sama sebagai deret asli.

$$
\mathrm{MAD}=\frac{\sum|D t-F t|}{\mathrm{n}}
$$

Keterangan:

$D t \quad=$ Nilai yang sebenarnya pada masa- $\mathrm{t}$

$\mathrm{Ft}=$ Nilai yang diramalkan pada masa- $\mathrm{t}$

$n \quad=$ jumlah masa yang dicakup

\section{B. Mean Squared Error (MSE)}

Mean Squared Error (MSE) adalah metode lain untuk mengevaluasi metode peramalan. Masingmasing kesalahan atau sisa dikuadratkan.Kemudian dijumlahkan dan dibagi dengan jumlah observasi. Pendekatan ini mengatur kesalahan peramalan yang besar karena kesalahankesalahan itu dikuadratkan. Kelemahan dari menggunakan Mean Squared Error (MSE) adalah bahwa cenderung untuk menonjolkan penyimpangan besar karena istilah kuadrat.

$$
\text { MSE }=\frac{\sum(D t-F t)^{2}}{\mathrm{n}}
$$

Keterangan:

Dt = Nilai yang sebenarnya pada masa- $\mathrm{t}$

$\mathrm{Ft} \quad=$ Nilai yang diramalkan pada masa- $\mathrm{t}$

$\mathrm{n} \quad$ = jumlah masa yang dicakup

\section{Mean Absolute Percentage Error (MAPE)}

Masalah dengan MAD dan MSE adalah bahwa nilai-nilai mereka bergantung pada besarnya item yang diperkirakan. Jika item yang diramalkan dalam ribuan, maka MAD dan MSE bisa sangat besar.Untuk menghindari masalah tersebut, kita dapat menggunakan metode Mean Absolute Percentage Error (MAPE). MAPE mengindikasi seberapa besar kesalahan dalam meramal yang dibandingkan dengan nilai nyata pada deret. Metode MAPE digunakan untuk membandingkan ketepatan dari teknik yang sama atau berbeda dalam dua deret yang sangat berbeda dan mengukur ketepatan nilai dugaan model yang dinyatakan dalam bentuk rata-rata persentase absolut kesalahan. MAPE dapat dihitung dengan rumus sebagai berikut:

$$
\text { MAPE }=\frac{\sum|D t-F t|}{\sum D t}
$$

Keterangan:

Dt = Nilai yang sebenarnya pada masa$\mathrm{t}$

Ft = Nilai yang diramalkan pada masa$\mathrm{t}$

\section{Hasil Dan Pembahasan}

\section{Profil CV. XYZ}

CV XYZ, merupakan sebuah perusahaan yang bergerak dibidang industri tepung tapioka yang berada di Provinsi Lampung tepatnya di Desa Bangun Sari Kecamatan Negerikaton Kabupaten Pesawaran. Perusahaan ini berdiri diatas lahan seluas $2000 \mathrm{~m}^{3}$ dengan jumlah karyawan mencapai lebih dari 100 karyawan tetap dan karyawan harian. CV XYZ memiliki omset sebesar Rp 700.000.000 perbulan (Usman, 2018).

\section{Peramalan Penjualan Tapioka}

CV. XYZ memproduksi tapioka dimulai pada tahun 1999. Penjualan tapioka CV. XYZ dilakukan berdasarkan permintaan konsumen. Jumlah tapioka yang dijual CV. XYZ tergantung dengan jumlah produksi tapioka yang mampu dihasilkan oleh CV. XYZ setiap tahunnya. Berikut ini 
merupakan data penjualan tapioka CV. XYZ tahun 2015-2019 yang disajikan dalam bentuk grafik, disajikan pada Gambar 1.

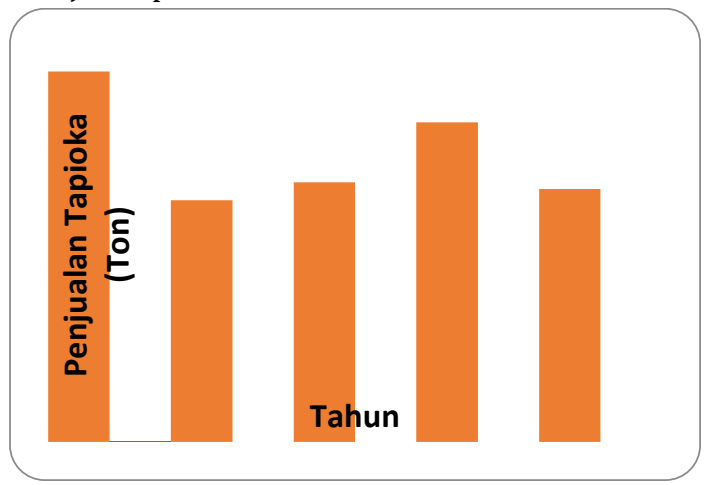

Gambar 1. Hasil Penjualan Tapioka tahun 2015-2019 CV. XYZ. Anonim (2019)

Peramalan penjualan tapioka merupakan penentuan tolok ukur penjualan tapioka CV. XYZ di masa yang akan datang. Peramalan dilakukan dengan cara melibatkan data penjualan tapioka CV. XYZ di masa lalu dan menempatkannya ke masa yang akan datang dengan menggunakan Software POM-QM for Windows Version 5.2 Data yang digunakan untuk melakukan peramalan yaitu data penjualan tapioka adalah data tahunan CV. XYZ dari tahun 2015-2019. Perhitungan Software POM-QM for Windows Version5.2 pada peramalan penjualan tapioka CV. XYZ menggunakan metode linear regression, moving average, wighted moving average, eksponential smoothing, dan eksponential smoothing with trend. Hasil perhitunganperamalan disajikan pada Tabel 2.

Tabel 2. Hasil peramalan penjualan tapioka CV. XYZ

\begin{tabular}{|c|c|c|c|c|c|c|}
\hline No & $\begin{array}{c}\text { Meto de } \\
\text { peramal an }\end{array}$ & & MAD & MSE & $\begin{array}{c}\text { MAPE } \\
(\%)\end{array}$ & $\begin{array}{c}\text { Peramalan } \\
2020 \\
\text { (ton) }\end{array}$ \\
\hline 1 & $\begin{array}{l}\text { Linear } \\
\text { Regression }\end{array}$ & & 3424,879 & 14948800 & 13,43 & 21800,75 \\
\hline 2 & $\begin{array}{l}\text { Moving } \\
\text { Average }\end{array}$ & & 3966,75 & 15735110 & 17,69 & 25593,4 \\
\hline 3 & $\begin{array}{l}\text { Wighted } \\
\text { Moving } \\
\text { Average }\end{array}$ & & 9171,191 & 88191740 & 39,87 & 19045,71 \\
\hline 4 & $\begin{array}{l}\text { Eksponential } \\
\text { Smoothing }\end{array}$ & $\begin{array}{l}\alpha= \\
0,90\end{array}$ & 5649,66 & 47038240 & 24,55 & 22955,1 \\
\hline 5 & $\begin{array}{l}\text { Ehsponential } \\
\text { Smoothing } \\
\text { With Trend }\end{array}$ & $\begin{array}{l}\alpha= \\
0,90 \\
\beta= \\
0,60\end{array}$ & 8247,582 & 71517810 & 35,45 & 20864,31 \\
\hline & & $\begin{array}{l}\alpha= \\
0,90 \\
\beta= \\
0,90\end{array}$ & & & & \\
\hline
\end{tabular}

Keterangan : - MAD (Mean Absolute Deviation)

- MSE (Mean Squared Error)

- MAPE (Mean Absolute Percentage

Error)

Berdasarkan Tabel 2, dapat diketahui bahwa metode linear regression memiliki nilai MAD, MSE, dan MAPE terkecil dari metode lainnya yaitu sebesar 3424,879, 14948800 dan 13,43\%, dengan hasil peramalan pada tahun 2020 sebesar 21.800 ton tapioka. Oleh karena itu, metode linear regression merupakan metode peramalan yang paling tepat digunakan CV. XYZ untuk memprediksi penjualan tapioka di masa yang akan datang. Hasil penelitian Prasetio (2014), menyatakan bahwa peramalan penjualan jas hujan dengan menggunakan metode linear regression memiliki nilai MAD dan MSE terendah dibandingkan dengan metode moving average, wighted moving average,eksponential smoothing, dan eksponential smoothing with trend. Selaras dengan pendapat Djie (2013), menyatakan bahwa peramalan penjualan produk polo shirt dengan menggunakan metode linear regression memiliki nilai MAD dan MSE terendah dibandingkan dengan metode moving average, weighted moving average, eksponential smoothing, dan eksponential smoothing with trend. Sedangkan hasil penelitian Yulius dan Yetti (2014), menyatakan bahwa peramalan kebutuhan manajemen logistik pada usaha depot air minum isi ulang Al-Fitrah dengan menggunakan metode linear regression memiliki nilai MAD dan MSE terendah dibandingkan dengan metode moving average, weighted moving average, dan eksponential smoothing.

Peramalan penjualan tapioka CV. XYZ menggunakan metode linear regression disajikan pada Gambar 2. Berdasarkan Gambar 2, diketahui bahwa penjualan tapioka pada tahun 2015 sebesar 32.830 ton dan mengalami penurunan penjualan tapioka pada tahun 2016 menjadi 21.400 ton. Akan tetapi, penjualan tapioka terus mengalami peningkatan pada tahun 2016-2018, dan pada tahun 2019 mengalami penurunan kembali sebesar 22.420 ton atau sekitar $6 \%$. 


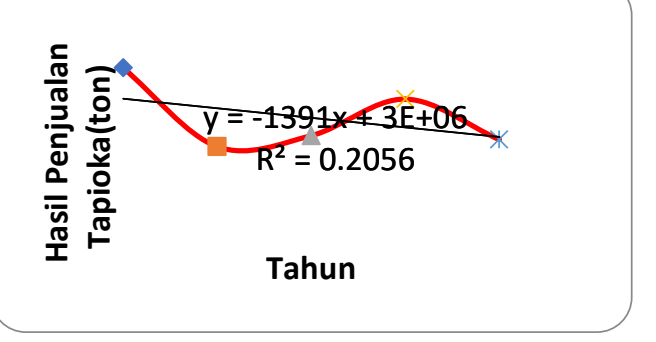

Gambar 2. Peramalan penjualan tapioka CV. XYZ menggunakan Metode linear regression

Pada Gambar 2, diketahui nilai regresi yang dihasilkan pada peramalan penjualan tapioka di CV. XYZ menggunakan metode linear regression sebesar $y=1391+3 E x+06$ dengan akurasi pembacaan $R^{2}=0,205$. Hal tersebut menunjukkan bahwa tren penjualan tapioka di CV.XYZ mengalami penurunan. Hasil peramalan penjualan tapioka di CV. XYZ pada tahun 2019 - 2023 disajikan pada Tabel 3.

Tabel 3. Peramalan penjualan tapika CV.XYZ pada tahun 2019 - 2023

\begin{tabular}{cccccc}
\hline \multirow{2}{*}{ Item } & \multicolumn{5}{c}{ Peramalan(Ton/Tahun) } \\
& 2020 & 2021 & 2022 & 2023 & 2024 \\
Penjualan tapioka & 21.800 & 20.536 & 19.272 & 18.000 & 16.743
\end{tabular}

\section{Validasi Metode Peramalan dan Realisasi Penjualan}

Validasi metode peramalan dan realisasi penjualan merupakan perbandingan antara jumlah penjualan tapioka hasil peramalan tahun 2020 dengan jumlah realisasi penjualan tapioka di CV. XYZ tahun 2020. Grafik validasi metode peramalan dan realisasi penjualan di CV. XYZ disajikan pada Gambar 3.

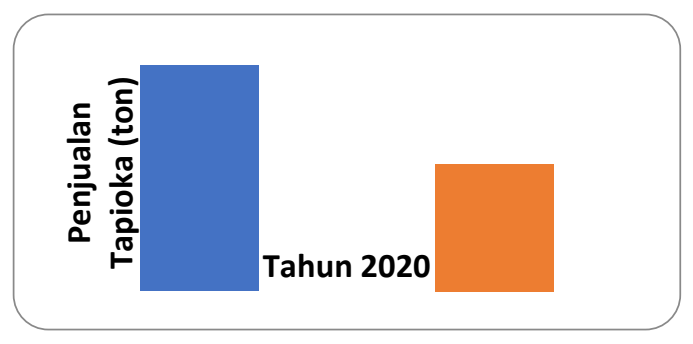

Gambar 3. Grafik validasi metode peramalan dan realisasi produksi di CV. XYZ
Hal ini menandakan bahwa berdasarkan peramalan dengan menggunakan metode Linear Regresi penjualan tapioka pada peramalan mengalami penurunan menjadi 21.800 ton pada tahun 2020. Sehingga terdapat selisih penjualan tapioka sebesar 620 ton. Hasil tersebut menunjukkan bahwa dalam melakukan peramalan penjualan diperlukan pertimbangan terhadap faktor-faktor yang dapat mempengaruhi tingkat penjualan tapioka. Hasil penelitian Prajawantoro (2015) menyatakan bahwa faktor-faktor yang mempengaruhi penjualan tapioka di CV. XYZ yaitu harga jual tepung tapioka, harga jual pesaing, biaya distribusi dan biaya promosi. Faktor biaya promosi merupakan penyebab utama penurunan penjualan tapioka di CV. XYZ tahun 2020.

Dengan mengalokasikan biaya promosi yang sesuai dengan perencanaan, kemungkinan terjadinya kesulitan penjualan tepung tapioka pada industri CV. XYZ akan berkurang, dan perusahaan juga akan maksimal dalam mengelola penjualan dan labanya. Kemudian pelanggan pun akan puas dengan pelayanan perusahaan karena kebutuhan permintaan pelanggan terpenuhi dengan tepat dan cepat (Rusiana, 2018).

\section{Kesimpulan}

Berdasarkan hasil peramalan penjualan tapioka yang telah dilakukan, hasil paling baik adalah menggunakan metode Linear Regresi dengan persentase kesalahan Mean Absolut, Percentage Error (MAPE) 13,43\% lebih kecil dibandingkan metode- metode lain yaitu moving average, wighted moving average, eksponensial smothing dan eksponential smothing with trend. Peramalan produksi tahun 2020 diperoleh sebesar 21.800 ton.

\section{Daftar Pustaka}

Anonim 2019. Penjualan Tapioka CV. Semangat Jaya Tahun 2015-2019. Tataan. Lampung.

Assauri, S. 2004. Manajemen Produksi dan Operasi.Fakultas Ekonomi Universitas Indonesia: Jakarta. 
Bahagia, S. N. 2006. Sistem Inventory. Institiut Teknologi Bandung: Bandung.

Baroto, T. 2002. Perencanaan dan Pengendalian Produksi. Ghalia Indonesia: Jakarta.

Direktorat Pengolahan Hasil Pertanian, 2012, Pedoman teknis pengembangan agroindustri tanaman pangan tahun 2002, Jakarta

Djie, I. S. J. 2013.Analisis Peramalan Penjualan dan Penggunaan Metode Linear Programing dan Decision Tree guna Mengoptimalkan Keuntungan pada PT Primajaya Pantes Garment. Journal The Winners. 14(2):113-119.

Gitosudarmo, H. I. 2002. Manajemen Operasi. Fakultas Ekonomi Universitas Gajah Mada: Yogyakarta.

Heizer, J., dan Render, B. 2010. Manajemen Operasi Edisi 9. Salemba Empat: Jakarta.

Nasution, Hakim, A., dan Prasetyawan, Y. 2008.Perencanaan dan Pengendalian Produksi Edisi Pertama. Graha Ilmu: Jakarta.

Prajawantoro. 2015. Analisis Faktor-faktor yang Mempengaruhi Nilai Penjualan Tepung Tspioks Pada CV. Srikandi Di Gaya Baru Lampung. Jurnal Manajemen dan Bisnis Vol. 5 no. 2 April 2015. 172-192.

Prasetio, R. T. 2014. Inventory Control Using Statistics Forecasting On Manufacture Company.Jurnal Informatika Universitas BSI. 2(2):136-142.

Rangkuti, F. 2004. Manajemen Persediaan Aplikasi di Bidang Bisnis.PT. Raja Grafindo Persada: Jakarta.

Ristono, A. 2009.Manajemen Persediaan Edisi Pertama. Graha Ilmu:Yogyakarta.

Rusiana Indah. 2018. Optimasi Perencanaan Kebutuhan Material Dengan Menentukan Peramalan Permintaan Produk Tepung Tapioka. Prodi Manajemen. Fakultas Ekonomi. Universitas Nusantara PGRI. Kediri. Jawa Timur.

Subagya, M. 1994. Manajemen Logistik. PT. Gunung Agung: Jakarta.

Usman Ali. 2018. Pengaruh Program Kemitraan dan Program Bina ingkungan Sebagai Tanggung Jawab Sosial Industri Tepung Tapioka Terhadap Peningkatan Kesejahteraan Masyarakat Perspektif Ekonomi Islam.
Fakultas Ekonomi dan Bisnis Islam. Universitas Islam Negeri Raden Intan Lampung.

Wardah Siti, Iskandar. 2016. Analisis Peramalan Penjualan Produk Keripik Pisang Kemasan Bungkus (Studi kasus Home Industri Arwana Food Tembilahan). Jurusan Teknik Industri. Fakultas Teknik dan Ilmu KOmputer. Universitas Islam Indagiri Tembilahan. Riau. Sumatera.

Winarno, F. G., 2004. Kimia Pangan dan Gizi. Cetakan ke-XI. PT. Gramedia Pustaka Utama. Jakarta.

Yamit, Z. 2003. Manajemen Produksi dan Operasi. Ekonisia: Yogyakarta.

Yulius, H., dan Yetti, I. 2014. Peramalan Kebutuhan Manajemen Logistik pada Usaha Depot Air Minum Isi Ulang Al Fitrah.Jurnal Edik Informatika Universitas Putra Indonesia Padang.1(11):5-14. 